\title{
Diary of an Iowan Under Fire in Peking
}

\author{
Edited by Henry Borzo \\ Associate Professor of History at Drake University
}

To some extent of course we outgrow history, but we can never entirely escape it. Even a brief glance at China and her relations with the West and at the end of the nineteenth century, makes more understandable China's attitude to the West today.

Throughout the nineteenth century, China generally resented Western pressures and influences. The sale of opium in ever larger quantities in China by the West had not lessened that resentment; nor had the influx of foreign missionaries in China always improved the latter's attitude to the West. Chinese traditionalism, which did not rate its own merchants too high, could hardly be expected to understand, much less to welcome, Westerners, equipped with guns, opium, merchandise and missionaries.

This resentment was augmented by China's defeat in 1895 by Japan, which was a signal for a fresh scramble for Western influence, again adding to China's unhappiness with the West. For instance, Russia secured the right to build a railway through northern Manchuria in 1896 and, two years later, the right to extend it to Port Arthur. Germany, because of the murder of two of her missionaries, extracted mining and railroad rights in the Shantung Peninsula. England then secured the territory of Weihaiwei on a lease and France obtained concessions in Kwangchow Bay. American interest in the Far East, though not involved in territorial concessions in China, was made obvious by our acquisition of the Philippines, Hawaii, Wake, Midway and Guam. Our interests in China were attested to by our "Open Door" notes of September, 1899, which attempted to protect our trade and investments. America also contributed numerous missionaries to the Chinese field, further complicating our relationship with the Celestial Empire because missionaries often became involved with the legal and economic concerns of native Chinese converts. 
Reports of alleged abuses against missionaries and native converts, and reports of half-hearted official attempts to correct such abuses, seemed to take up most of the time of the American representatives in China. ${ }^{1}$ The conduct of the foreigners in China was, according to one student of the period, "often deplorable and always open to misconstruction." Here was the cause of much of the trouble. The inability of the Manchu dynasty to cope with the onslaught of Western civilization, only served to heighten her irritability. Perhaps because the dynastic power did not know how to act, it connived at cooperation with the secret society known as Boxers and supported the latter's rebellion against the foreigners.

The Boxers were so called because they were ostensibly a society making boxing and gymnastics their purpose, but on their flags they had the mottoes, "Cherish the Dynasty" and "Exterminate the Foreigner." Their members passed through various ranks, each confirmed by mystic rites and the highest class of initiates believed themselves invulnerable to sword, spear or bullet. The Boxers began raiding villages of Christian converts in 1899; their rebellion against the hated foreigners, missionaries and Christian converts reached its height in the summer of 1900 when they attacked the Legation area in the Tartar City in Peking. (See map I) This area, with its over 500 inhabitants, about half of whom were missionaries, was cut off from the outside world completely during the siege. The members of the foreign legations, together with the missionaries and natives, lived in a state of terror from day to day, through June, July and till mid-August when they were relieved by an international force.

The diary which is here printed for the first time was kept by the wife of a secretary of the American legation in Peking -Mrs. William E. Bainbridge, of Council Bluffs, Iowa. She was the former Mrs. M. A. McCargar, 40 years a resident of Council Bluffs, who had only been married to Mr. Bainbridge since 1894. Mr. Bainbridge had been appointed second secretary to the American Legations in 1898.

Though this diary does not bring to us any startling altera-

${ }^{1}$ U. S. State Dept. Archives, Despatches from U. S. Ministers to China, 1897-99.

2 Peter Fleming, The Siege of Peking, Harper \& Bros., New York, 1959 , p. 24. 
tion of the record of the summer of 1900, it does bring us an account by an eyewitness of much of the siege of Peking and helps us to imagine the spirit of those terrifying days. The general climate of opinion is often more accurately gauged from the testimony of an observer not directly involved in an official capacity, than from the official record itself. In so far, for instance, as Mrs. Bainbridge was unaware of some of the larger aspects of the whole problem of Westerners in China, we may perhaps find a clue to some of the mistakes the West made in its relationships with China. That she was able to see only the ingratitude of the Chinese, can be compared to the inability of the Chinese to see the "logical" relationship between opium importation and Christianity. That she stressed "noise" more than anything else reminds the reader of the fact that even in centuries past the Chinese had used gunpowder more for fireworks and display than for war. Though there was of course terrible and extensive damage, her emphasis on "noise" gives the reader at times a fantastic if not unreal impression, and suggests the fantastic and unreal, or unsolved, problems of why the Chinese government supported the Boxers, and why, having supported them, they did not use all the guns at their command, and finish off the foreign legations in a day or two.

To follow Mrs. Bainbridge's account it is helpful to consult the map of Peking and the map of the Legation area. There were eleven legations and they occupied an area of about three-quarters of a square mile, just to the southeast of the Forbidden or Imperial city. On the south they were bounded by the wall of the Tartar city, some 40 feet high. A railroad, one of the three in China in 1900, extended from a point a few miles from Peking, to Tientsin. This railroad, and the telegraph line accompanying it, were destroyed, cutting Peking off from the rest of the world. During the siege, 66 foreigners were killed, six persons had died and over 150 had been wounded. ${ }^{3}$

The diary is here reproduced in its entirety, without alteration. The few peculiarities of spelling have been allowed to stand. Apostrophes have been added to show possessive case and in the word o'clock, to make for easier reading.

${ }^{3}$ Fleming, op. cit., p. 211. 


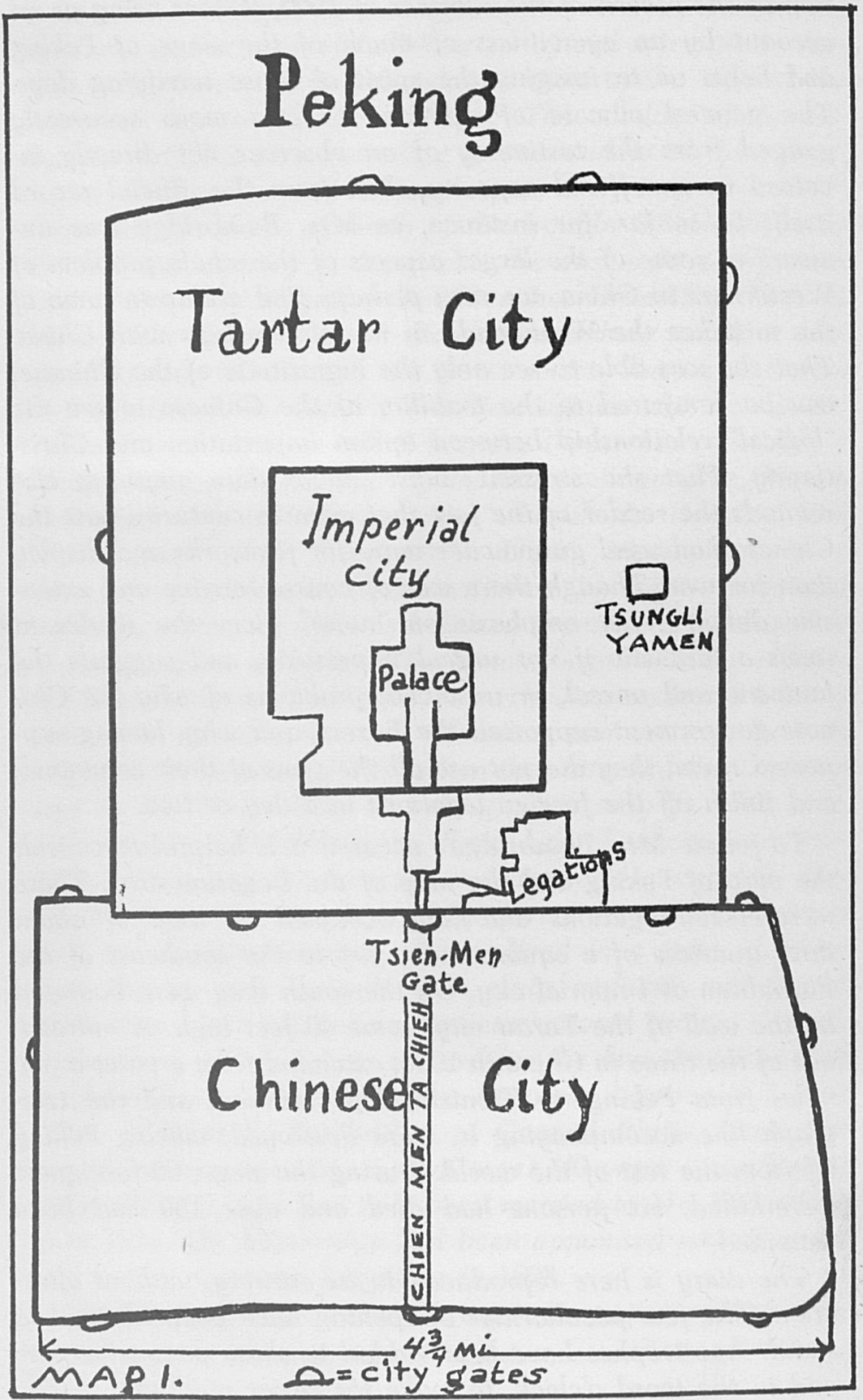

Map of Peking Showing Legation Area 


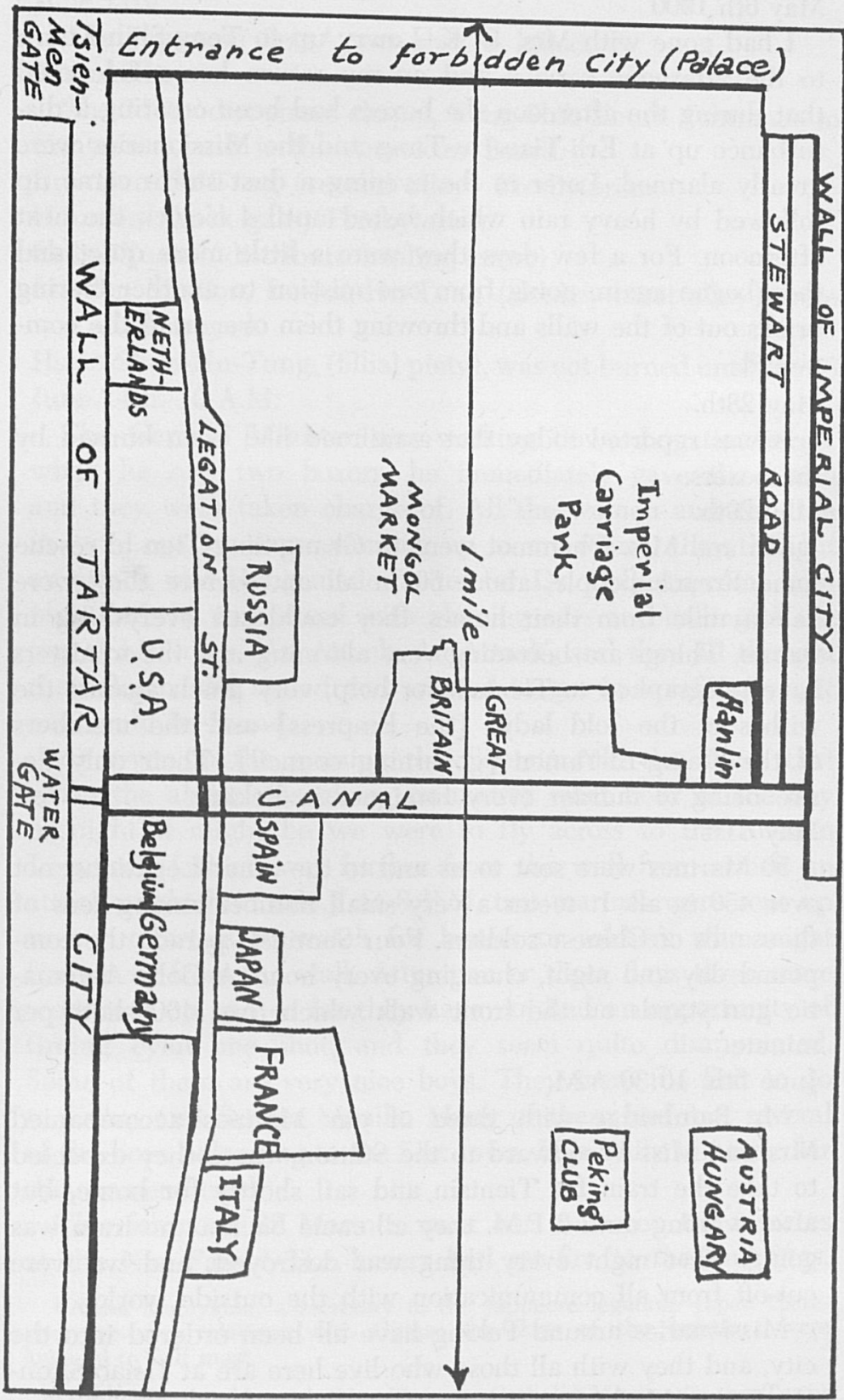

Map of Legation Area 


\section{May 6th 1900}

I had gone with Mrs. E. K. Lowry up to Teng-Shih-Kourh to the afternoon service and on my return home I learned that during the afternoon the boxers had been creating a disturbance up at Erli-Tiao-Hu-Tung and the Missionaries were greatly alarmed. Later in the evening a dust storm came up followed by heavy rain which lasted until 4 o'clock the next afternoon. For a few days they were a little more quiet and then began again, going from one mission to another tearing bricks out of the walls and throwing them over in to the compound.

\section{May 28th.}

It was reported today that a railroad had been burned by the boxers.

May 29th.

Mr. and Mrs. Chammot went to Chang-Sing-Tien to rescue some French people, about 60 in all and before they were half a mile from their homes they could see everything in flames. Things are becoming very alarming and the ministers have telegraphed to Tientsin for help, very much against the wishes of the "old lady" [the Empress] and the members of the Tsung-Li-Yamen [governing council]. Their only desire being to murder every foreigner in Peking.

May 31st

50 Marines were sent to us and to the other Legations, not over 450 in all. It seems a very small number among tens of thousands of Chinese soldiers. Four Sentinels parade the compound day and night, changing every hour. A Colts Automatic gun stands on the front walk which fires 400 shots per minute.

June 5th. 10:30 A.M.

Mr. Bainbridge with three of our Marines accompanied Mrs and Miss Woodward to the Station where they expected to take the train for Tientsin and sail shortly for home, but after waiting until 3 P.M. they all came back as no train was going. That night every thing was destroyed, and we were cut-off from all communication with the outside world.

Missionaries around Peking have all been ordered into the city, and they with all those who live here are at Hsiao-ShunHu-Fung (Methodist Mission.) 
June 11th.

The Japanese Sect. ${ }^{4}$ was shot \& killed. June 13th.

The Methodist street chapel, Teng-Shih-Kourh (entrance to Canteen. . .and is the American Board. Erli-Tiao-Hu-Tung (second alley) Presbyterian. Houmen (back gale) Presbyterian.

Shih-I-Yuan, (distribute healing court).

London Mission, Lu-Jou-Hu-Tung (donkey meat alley) were all distroyed.

Hsiao-Shun-Hu-Tung, (fillial piety), was not burned until the 23 June 14th. 10 A.M.

The German Minister was walking down Legation street when he saw two boxers, he immediately gave the alarm and they were taken charge of. All the women and children in our Legation came running up to my rooms, they thought an attack was being made on us, for Dr. Collinan came running into the compound with glareing eyes and calling to the top of his voice, 'An Attack, An Attack', and they all thought their doom was sealed and wanted to get to a safe place, if one could be found.

At seven in the evening the Captain told the ladies that when the alarm was given, no matter what hour of the day or night it might be we were to fly across to the Russian Legations [which was further from the wall from which an attack might be made.] At 8 P.M. two marines were sent up to our quarters to watch for boxers or soldiers who might fire on us from the wall. After two or three days three more were sent up and so far they have not had an opportunity of fireing even one shot, and they seem quite disappointed. Some of them are very nice boys. They were the first to go to Cuba, and first to Manila. Many of them had met several of the boys belonging to the 51st Iowa. Bob Daily in particular they remembered.

This forenoon 22 Marines went out to rescue the inmates at the Nan-Fang. ${ }^{5}$ The boxers had set fire to the buildings,

4 Akira Suguyama, a secretary in the Japanese legation. Japan thereupon severed relations with China; the flags of the legations were lowered to half mast.

5 Probably should read: Nan-Tang, a Catholic Mission in the Tartar City. 
after tieing some of the most helpless women and children to posts, trees or their beds, and torturing them in a most brutal manner. These barbarians are most wonderfully brave where there is notone but women and children. The boys shot 62 boxers, and brought all the refugees back with them who were not dead or dying.

An old Ahma of Mrs. Squiers ${ }^{6}$ who had gone out there on Sunday to communion, intending to return on Monday but was unable to get back came in with the others. Her youngest son was one of the Priests and was among the number who was burned to death. I went down to see the old lady and she told me that in "one hour more she be all finnee."

I have had a few things in a handbag, my umbrella and hat near the doorway ready to fly at a moments warning, since the 10th. This afternoon a number of German, English and Americans went out and shot 40 more of these brutes. I was out near the gateway when our boys came in, following behind some distance were about a hundred or more refugees hobling along as best they could, all bruised and bleeding from their wounds. One young girl who was being led by her companions was blind, her eyes had been dug out of her head, another had a wound on the back of her head and the brain exposed to view. They all sat down on the walk in the shade to rest and get a cool drink. The Army Surgeon dressed the wounds. I noticed one little boy whose hands were burned almost to a crisp and his poor little bare back was all bruised and blistered. And yet there was not a murmur, all was still as midnight except when the surgeon asked for something.

Saturday morning the Marines were called to go to the outer gate, as boxers were coming in great numbers to the inner city. So they hurriedly set out to greet them, in about an hour when they came back saying they had killed 62 and the rest had gone home to tea. They also told us the outer city was in flames. One of our guards shot 10 boxers and another killed 4 . In the evening the Russians shot two Chinese soldiers who they caught setting fire near our Legations.

At 10 P.M. we all went upon the wall to look over at the burning of the outer city and the once beautiful gateway. All the silk shops, curio shops and all manner of places were all

${ }^{6}$ Wife of the 1st Sec. of the American legation. 
going up in flames and smoke. [This was the very wealthy business quarter which the Boxers destroyed along with many of the Legations.] They were not handsome to look at, little tumble down looking buildings and nothing to show whether you were entering a Joss-house, ${ }^{7}$ Junk-shop, silk shop or an opium den. Many thousand were homeless in less than 24 hours.

June 17th.

At 3:30 A.M. we were aroused from our peaceful slumbers by quick rifle shots on or near the wall and hastily dressing went down stairs to see what was going on, by the time we got down Captain Meyers, [in command of the Marine Detachment guarding the American Legation] came to tell us what it meant. Some Chinese soldiers were seen sneaking along the wall and our boys fired on them. The Chinese very quickly gathered themselves together and took to their heels, did not wait for a second a salute so early in the morning. We went to bed again, but did not undress, had to further occasion to be further alarmed until during the forenoon the Germans and Austrian soldiers had a small battle with Chinese soldiers killing 30 more of them.

June 16th.

The captain took our guards and put them on the wall last night.

June 17th.

At 10 P.M. Sunday evening 3 officials from the Tsung-Li-Yamen came for an interview with Mr. Conger [an Iowan who was American minister to China] and also to present him with the Empress Dowagers compliments, saying she was very anxious for the safety of the foreign Ministers and all connected with the Legations, Especially Americans. They were not however anxious we should have any more troops here and very reluctantly gave their consent. They were served tea, after which they went home, seemingly in a very peaceful frame of mind. We all went to bed and slept quite peacefully until 7:30, June 18. The officials having assured us the Chinese soldiers should not interfere with us. The night was very quiet, a number of our guards seeing them safely outside the picket-line.

${ }^{7}$ Popular expression for a Chinese temple. 
June 18

Everything is quiet, and all we can hear is the click of typewriters and the tread of Marines, (childrens voices thrown in.)

June 19.

At 4 P.M. a messenger came from the Tsung-Li Yamen saying we had been given 24 hours to leave the city. ${ }^{8}$ It was not a very happy night for any of us, for it was utterly impossible to get away. The train had been distroyed, the carts all taken to the outer city and we saw nothing but death stareing us in the face. The next day the Ministers decided to call all foreigners together and go to the British Legation (it being the largest of all) and try to fight it out until relief came.

June 20.

Baron Von Kettler, [German Minister to China] was shot while on his way to Yamen, his Interpreter was wounded, but did not die. The Ministers body was not recovered.

At noon all the missionaries came pouring in to our compound, bringing nothing with them only what each one could carry in their hands. There were nearly one hundred men and women and children. It was a pitiable sight to look upon them as they came marching in, homeless and forlorn, their possessions all gone. As I stood in the doorway of the office building watching them as they came along my heart seemed to almost stop beating. I never had witnessed such a scene before. I shook hands with each as they drew near, those I had not seen before as well as the ones I had become acquainted with. I could not speak, my heart was too full for utterance. As Mrs. Lowry came along alone (for her husband was caught in Tientsin and could not get back,) my heart went out for her. She looked so forlorn, she pressed my hand warmly and neither of us spoke a word, but walked away silently to a quiet corner in the compound where we were alone. The last time I had seen her was the day before I went to Tientsin when she came down and spent the afternoon with me. Every thing had change during those few weeks. I had gone with Mrs. Hoover to Tientsin, had very suddenly

8 Since the Taku Forts had just been taken by the Allied forces, a state of war was said to exist and foreign representatives would be expected to leave. 
been called home, Mrs. B. was dangerously ill, we were in quarantine ten days, and when she and I met again, she was a homeless wanderer in the streets of Peking, and alone. After every one had a lunch we gathered up a few things and all came over to the British Legations. The British Minister and his wife (Sir Claud[e] and Lady MacDonald) had every thing all arranged and we are much more comfortable than we had anticipated. The missionaries are quartered in the English chapel which is not very large, so a number of the ladies sleep in Lady McDonald's ballroom. The two foreign merchants gave over their stores to be used for all, and soon as things could be brought in it was done.

June 22.

The fire alarm sounded at 5 P.M. A fire was discovered just outside the wall of this Legation, and for some hours we almost gave up in dispair, but after heroic work on the part of men, women and children, carrying water, it was finally subdued. Considerable fireing was done on both sides of the wall. One English and one German marine were shot.

Our American boys are still holding our Legation and will do so just as long as it is possible for them to do so. June 23, 1900

We had rather a quiet night after the fires died out and the fireing ceased.

These boxers are said to be Spiritualists. Dr. Amment of the "American Board" says the origin of the boxers is made up of 64 different religions. They are working with the belief that what they are doing does not come from them selves, but from dead spirits, and they believe they cannot be killed. This, however, has been proven to be false. They are an immense army, and have been accumulating for years to make this bold stroke. They do not come in large numbers, but small groups. They think foreign people are to blame for much of their poverty, that is in taking away their employment in building railroads, steamboats and many other things which is causing so much of their work to be of no value to them so far as money is concerned. A Chinese can only do one kind of work. If he is a cook and has lost his job, he knows nothing but to starve, and all other workman likewise. And it has been so for generations back, and no doubt 
will be so to the end of time. There are two elements, none between. The hostile and the friendly. Those who have lived here 30 or 40 years cannot say they are sure which class they are running up against. Dr. Martin, President of the Tung Wen college, and who has lived in China 50 years said he did not know of one friend he could rely upon among any of them.

11 A.M. A terrific fire broke out at the back of this compound, but as before, was subdued by a great effort on the part of all.

At 2 P.M. fires were discovered at the front \& on the left and it seemed that we were to be soon in a sea of fire, again it was quieted down. Heavy fireing was kept up all afternoon and all night, a very large number of boxers were killed and several hundred Chinese soldiers. One American Marine was shot and one Italian. One English and one Russian wounded. Our American flag was wraped around the dead body of our Marine and he was laid to rest in the Russian Legation compound.

The Russian bank and the customs were burned last night. June 24. Sunday.

Our foreign soldiers have been trying to capture the Chinese gun which is stationed near us, but after making three attempts with no success they gave it up. June 25th.

At 1 A.M. we were awakened by heavy fireing, and as we have done for many nights passed, got up and put on our clothes. After an hour or so the ladies relieved without undressing and slept until daylight. All the men being on guard in different places.

At 9 A.M fireing began again and has been somewhat lively ever since. Bullets are whizing through the air from all quarters. 5 o'clock P.M. a proclamation was posted up at the bell tower saying, Chinese had been ordered to stop fireing on foreigners. The officials had sent a messenger from the Tung-Li-Yamen, saying the Empress Dowager had given the order, but as we had lost all faith in Chinese powers no one believed it to be anything but false and went to work harder than before, making sand bags, building more barricades, digging trenches and all manner of things so that should the 
Chinese make an attack that night everything would be ready for their reception.

One German and one Japanese were shot and two Americans wounded during the day.

Most of us went to bed rather earlier than usual in order to get a few hours sleep if possible. At 12:30 we got up in a great hurry as the heaviest fireing we had ever heard was close around us. They came upon us like a thunder clap. The shots were quick and it seemed as though there were thousands of soldiers outside the compound. I did not go to bed it seemed so awful, Mr. B. went on his watch at 1 oclock and thought I would sit here and write while he was out. 3 A.M. we tried to sleep after the fireing ceased, as we supposed, but very shortly they began on us again an[d] no one got any more rest all night. Seargent Fanning of our Marines was killed early this morning and one wounded.

June 26.

Considerable shooting was done all afternoon, but no accidents to our men. At 7 P.M. very severe fighting began and for a time was thought our American boys must give up their position on the wall, but the brave fellows held their place amidst shot and shell and drove the Chinese back. 3 A.M. June 27. Another attack which lasted until daylight. I do not know that even one foreign soldier was scratched.

Eleven A.M. Annother attack which lasted all day long. We felt quite sure that we should have a quiet night afer the anxious day, but we had no sooner closed our eyes than there was the sound of general alarm. "All civilians, to arms," None of us went to bed again that night.

June 28.

Shells were being fired at us from the Imperial palace wall, but all the damage done was a horse killed.

10 P.M. Shots were heard not far away which became louder and nearer and we had no rest all night. Chinese were killed in great numbers, but not one foreign soldier was hurt. June 29.

Shells were fired into the Foo where the refugees are living, but no one was hurt. The Italians turned their big gun on them and they quickly retreated.

This afternoon our Navy Surgeon was wounded by a stray 
bullet and was brought into the hospital. It is feared he may loose his limb.

7:15 P.M. The noise has begun again and we are keeping in the shade.

Trenches are being dug in many places where we are to run into in case of necessity. We thought to have a quiet night, but by the time we were settled comfortably in our beds the noise began and we got no more sleep until 5 A.M. the 30th. 10 A.M. Bullets are flying through the air thick and fast, it is not safe to be outside. June 30, 1 P.M.

Rather more quiet after the terrible night we passed through. One of our boys was shot this evening and another wounded.

Mr. Conger, Mr. Knoble, (Dutch Minister) Mr. B. Dr. Wherry, a Russian soldier and our little hospital steward, who at all times has a smile on his boyish face, burried the Marine at 9 P.M. by the side of his two comrads in the Russian compound.

July 1st.

Last night was quiet and no shots have been heard up to 11:30 when things became suddenly more exiting. Three Italians were shot and two of the customs boys wounded. Later in the day of the customs boys was killed.

5:30 P.M. Another of our Marines was shot. Mr. B. with the little sailor lad have gone to see about diging the grave, then when it is dark the body will be brought down from the wall and buried. Dr. Wherry will read a service at the grave.

This has been a very sad Sunday for us all and a very busy one. The ladies have made 2000 sand bags today to use on the wall for barricading. Our little handful of Marines are still holding it and we must help save their lives by serving just as fast as we can. A certain lady ${ }^{9}$-who claims to be a faithcure and a fanatic on religion came along when several of us were sitting outside the chapel busy as bees and said; "Now ladies, let us lay aside our work and go inside to have a few prayers. I think it will strengthen the courage of our dear boys on the wall." Some of them put down their work, but Mrs. Lowry, Mrs. Killey and myself still sat there. I did

${ }^{9}$ Possibly Mrs. Conger. 
not know their thoughts, neither did they know mine. Mrs. Smith looked at us, the said, "come, arn't you going in"? I finally said to her that I could pray and sew at the same time and I would not give much for a person who could not, and that while bullets were flying over our heads by the thousand that sandbags would be of lots more use just now in saving the lives of our boys on the wall in their awful position than prayers. So we three sat and sewed while the rest held a prayer meeting. Shells were exploding all about us, cannons booming and shot could be heard on all sides. It seemed to me that it was wicked to waste one minute in anything that was not to help save the lives of the 20 or 30 brave Marines who were holding the wall and driving back thousands of Chinese soldiers. We have been expecting a relief from Tientsin for many weeks but so far have heard nothing, if they do not come soon it seems as if we must give up.

July 2nd.

Loud fireing and heavy shelling all afternoon. July 3rd.

Early this evening we were heavily attacked and the fireing was kept up all night, then a heavy rain set in and all was quiet. During the night two of our Marines and one Russian were killed. Our Marines had made a charge on the Chinese and took one barricade. Captain Meyers who was leading the men, was wounded in the right leg. Mr. B. is now at the Russian Legation attending to the burrying of the Marines. It is very dark and gloomy and the rain steadily falling. Our boys have all been burried after dark or, when it was raining.

Some of the missionaries have been going around barefooted in order to save their one pair of shoes. Many of them have been burned out of house and home, many have nothing left-only what they have on their backs.

Relived at 9-30 thinking all was peaceful, but at 9-40 we bounded out and hustled into our clothes, as we have done almost every night for five weeks, and when I undressed again it was 7 A.M. July 4th. It seemed as though all the powers of hell had been let loose. Chinese were killed in great numbers and are lying all around us. Only one foreign soldier 
wounded and one Italian shot. 36 Marines have been killed and 53 wounded.

July 4th.

Captain Percy Smith commanded our Marines on the wall today. $\mathrm{He}$ is an Englishman and our boys think a great deal of him. This day is one none of us shall forget so long as we have our reason left us. The noise is something terrible. We have made sandbags all day long. Not a curtain of any discription has been left in our homes, no matter of what material they were. All have been used also tablecloths, sheets, and everything which would hold sand has been cut up and made use of. When we had used everything we had the soldiers looted Chinese shops and we have cut up some very beautiful silks, velvets and all sorts of lovely goods. July 5 th.

Last night was rather more quiet, most of us slept the greater part of the night. Occasionally we heard shots, but not noise enough to get us out of our beds. About daylight the Chinese began shelling on us again, but did no partiuclar damage.

12 A.M. Mr. Olifant was wounded very seriously and died at 2 P.M.

The Chinese had their big gun mounted inside the palace grounds and we understood they expected to put us out of existence before morning. 10 P.M. The racket began and lasted all night, early in the morning the Chinese got worn out and relieved to drink their tea and cool off. And we are still on deck.

It is said they always carry with them a teapot and pan no matter where they may be going, or on what business they are to attend to.

July 6 th.

The shells are still falling all over and around us, but no one hurt.

July 7 th.

A quiet night but early this morning the serenading began and is being kept up rather lively.

At noon a shell came through the roof into Sir Claud[e]'s dining room and fell in the center of the table which was all 
set for tiffin [luncheon] cut-glass and china were scattered all over, but no one was hurt.

The Chinese made another attack on the French Legation during the forenoon, two French Marines were wounded and the French Minister slightly. For a few hours in the evening it was quiet, but at 10- the noise began and were kept awake all night.

July 8th.

There was a report last night that Russian troops were nearing us but no one could prove it.

This afternoon some coolies saw the American gunner trying to rig up a big gun out of some old things which had been found, and after watching him for some time two of them started away and in a short time they returned bringing with them an old English gun which they found in a Chinese shop not far off. It was brought here in 1860. Our gunner looked at [it] with a smile, laid aside his other work and set himself to work up the one which the coolies brought in. He had it mounted on an Italian carriage and with Russian shells which the Russians could not use, the American gunner fired it over into the Imperial city about 5 P.M. and it proved a great success, as the Chinese got up to "look see", what had happened they were picked off in great numbers.

And we all rejoiced at their loss. July 9 th.

Very noisy all night. In the early part of the evening it was rather quiet and I went to my room thinking I might be able to take a sponge bath, but by the time I was undressed they began such a racket that I hustled into my clothes and concluded to wait until a more convenient season in which to bathe.

July 10th.

We got very little sleep last night because of the noise. July 11th.

At eleven A.M. the Chinese began shelling on us from the Imperial grounds, which is not far from us. Three shells came inside the compound, one going through the gate-house, making quite a hole, but killing no one. They all landed in the tennis court, which is in the center. Everyone sitting outside were ordered indoors, (after the bombs had exploded). We 
had a quiet afternoon and were greatly surprised at not having to get up after going to bed.

July 12 .

A German soldier was killed this afternoon and two others wounded.

July 13.

Last night was more quiet than usual, so quiet in fact that we could not sleep. The change was too great. Early this morning the Chinese have been blazing away at us with their big gun, but no one has been hurt. Yesterday 18 Chinese Soldiers were caught setting fire in the French Legation and they were every one shot. Later in the day fourteen boxers were found doing the same thing and like the soldiers were shot. This morning a boxer walked into the French Legation and gave himself up. He was taken to the American Legation to be interviewed by Mr. Pettrye. He said all the foreign portion of Tientsin was burned, and that foreign troops had taken the forts at Taku, that 40 thousand troops were on their way here, ${ }^{10}$ also that 3000 Chinese soldiers had drawn their pay and left the city. They locked him up over night and will see what more he has to say in the morning and whether his stories hang together.

July 14 .

At 9:30 last evening shots began to fly thick and fast and it seemed for a time that the Chinese would overpower us, but as before our boys got the best of them. The noise was kept up all night and we got very little rest. Shells have been falling right in our midst and still we are alive. Two French Marines were wounded during the night. Our men captured two Chinese flags this afternoon. A few minutes ago an Italian Marine was shot. His head was shot off. Two Germans and one French were wounded. It has been a very anxious day. At 6:30 P.M. 500 Chinese soldiers came down the back street and our boys on the wall did not miss an opportunity to fire into their midst and in less than 10 minutes 45 of them were shot, the rest took to their heels and fled much quicker than they came. Another crowd of them attacked the French Legation, also the German and the noise was something

10 Another rumor; relief expedition would not be leaving Tientsin till Aug. 4. 
never to be forgotten. They did not cease fireing until daylight. Both Legations are badly damaged. Three French Marines were shot, two could not be taken out from under the ruins. Three were wounded.

3:30 P.M. An Italian and one of the French Marines were buried this afternoon

A messenger came in from the Yamen with a letter to the Minister in which it said, "Ministers and their staffs were to come to the Yamen [Tsung-Li-Yamen or Governing Council] for protection and must come without guards and unarmed." The Ministers, however, took no stock in what the man said. Every one who wishes to enter our gates must have a pass (Chinese I mean). All the servants have a card pined in their sleeves, and if they go out without it they cannot get back.

The cannons have been booming the greater part of the day and two or three attacks have been made. One of the custom's young men had his jaw broken by a shot. July 15 th.

Last night we had quite a heavy attack and at 1 A.M. on the 16th of July one of our Marines was killed on the wall. There had been a battle and the night was one long to be remembered by everyone. The captain of British Marines was killed and one of the English students. At 2:30 P.M. we buried our American boy by the side of his six companions in the Russian Legation compound. All of the Legation ladies and many of the missionaries went over to the funeral. Mr. B. had already gone over to superintend the digging of the grave and we went over with Mr. Conger. We gathered what flowers there were to be found and some green leaves to strew over the graves of all. It was the first one of our boys who had been buried when ladies could go. The rain was falling softly down on our umbrellas and the tears silently rolling [down] most of our faces. I stood at the foot of the grave and I looked down upon the form of the poor boy lying in the cold ground dressed in his blue clothes and an American flag wraped around his lifeless body I thought of the poor mother at home whose heart would be sadly grieved did she but know how her boy had fallen in trying to save others. He gave his life for all the nations represented in Peking and his 
work is done. Dr. Wherry took charge of the services after Mr. Conger had made a few remarks. Three of his comrads were there to help Mr. B. Mitchell (the gunner) Young and Stanley, The Sailor lad. As I was puting the flowers on all the graves and was coming out I shook hands with the three boys and they could not speak they were almost heartbroken. I have tried to imagine a soldiers funeral in a foreign land, but never dreamed it would ever by my lot to be in the midst of battle or drop a tear over an American Marines grave in far-off China.

At 5:30 P.M. the British Captain and Mr. Warren, the British student, were burried in this Legation. Mr. Norris, Rector of the little English chapel here in the compound, officiated, both bodies were laid in the same grave. The British flag was wraped around their bodies and quantitites of flowers were strewn over them. The rain had ceased so that it did not seem quite so bad as when two hours and a half previous we laid our American boy to rest.

July 17

It was not such a bad night as the past three, only one attack was made, and so far, as I can learn only one British Marine wounded. We have used up what goods we had for sand-bags and I am going to find something to make a doz. handkerchiefs for our Marines, the poor fellows have very little of the necessaries of life. Their clothes were all lost excepting what they had on their backs.

Five or six Chinese soldiers gave themselves up today at the French and German Legations today and were brought here to be interviewed. One of them had been slashed over the ear by his commander because he did not blow his horn loud enough to suit him. When they wish to get their troops together they begin blowing horns and you never heard such awful sounds in your life.

At six o'clock a messenger came with a telegram for Mr. Conger. The Chinese Minister is supposed to have sent it. $\mathrm{He}$ inquired after the health of Mr. Conger and that is about all we could make out of the message.

The Yamen sent word that their troops had been ordered to quit fireing on us, but we are inclined to think they only 
mean to work out some other plan to destroy us. ${ }^{11} \mathrm{Mr}$. Conger had a notice posted up on Legation street saying if the Chinese build any more barricades on the street they would be fired on, but they paid no attention to it and went right on with their work and consequently our boys turned the gun on them and blew the barricades down, killing a few Chinese. It was quiet the rest of the night.

July 18.

Very quiet. We walked over to our Legation to see how things looked and see what had happened since we left it. Four weeks had passed since we all fled to the British Legation and desolation was on every side. The gate-house was badly shelled, trees cut down and lying in all directions, bullet-holes everywhere. In our rooms I counted 66 bullet-holes. The windows all broken, blinds hanging by one hinge, and one place in our bedroom where a shell came through, large enough for a mans body to get in, Carpets and furniture ruined.

At 2:30 P.M. a Japanese messenger, who had been sent out on the 30. of June, returned from Tientsin with a message saying foreign troops had taken Tientsin and the Chinese General had committed suicide, also that on the 20th. 30 thousand solidiers would start for Peking.

July 19.

More quiet last night and continued so all through the day. July 20th.

Nothing unusual transpired during the day, excepting two loads of mellons were sent down from the Yamen with compliments. Mellons will do very well after a substantial meal of fried chicken, mashed potatoes and all sorts of good things, but when one has been living for six weeks on rice and horsemeat three times a day, with shot and shell booming all around you, mellons are not very palateable. I presume they thought if they could not kill us with powder and shells they might succeed with choleramorbus. A few people ate some, but I did not care for any. The days and nights are excessively hot and many children are very sick. The past four days I have been with Dr. and Mrs. Inglis helping take care of

11 There was a sort of half-way truce beginning on July 17th, and ending about July 28; during this period two loads of fruits, vegetables flour and ice were sent to the Legation area on order of the Empress. 
their little baby who is dangerously ill. Three babies have died since we came in here. The German merchant where we used to take our meals when we first came to Peking, burried two within 10 days. The poor little things were simply wraped up in a sheet and taken by one or two men to the German Legation to be burried. A few days later another little child died and was burried in a little rough box.

July 21. Shooting all night.

July 22.

I came to my room at $5 \mathrm{~min}$. to 12 o'clock last night thinking the baby was better. The Dr. said "I think the baby is some better, so get a good nap tomorrow morning, don't come over so early." Just as I was finishing my breakfast a messenger came saying, can you come quick? the baby is sinking rapidly. I hastened away and found the father and mother almost heart-broken, their home and possessions all burned and now the baby was soon to be taken from them. It was a sad Sabbath morning, we watched by her little bed quietly and just as the clock finished striking the noon hour her little spirit took its flight. One of the missionary men made a little casket of pine boards and the ladies covered it with white flannel and lined it with some white silk which the ladies found. We found some little white flowers and with a few green leaves, tied them with some satin ribbon Mrs. Conger sent over. I put a little pink rose in her left hand and as we looked at the little form lying there so quietly, while bullets were flying over our heads outside, we could not but feel that it was all for the best. "Just as the sun went down" we laid the little lamb beside the brave soldier boys who had given their lives in trying to defend hers. July 24.

The Japanese interpreter who was wounded some time ago died this morning, and an Italian shot. July 25.

At 1 A.M. we were suddenly aroused from our slumbers by the familiar sounds of shots and for half an hour or more the noise was something terrible. One of our Marines was shot. Yesterday was the Emperor's birthday and it was being celebrated in the usual way and I presume they thought they would give us our early morning serenade. 
July 26 .

The report last evening was that our troops were half way between here and Tientsin, that they had fought a battle and driven the Chinese back some distance which we hope is true. July 28.

For two days it has been very quiet until 2 A.M. when they fired a few shots at us and retired.

It is reported that 40 thousand Chinese soldiers have gone out to meet our troops, taking with them 24 big guns, and that a battle will be fought at Tung-Chou, 12 miles from here. We are all very anxious to know what will be the result of the battle. It took our troops 24 days to take possession of Tientsin.

Last evening three or four cartloads of vegetables, flour, and ice were sent here, whether to poison us or what is the question in our minds. We understand the "old lady" and her crowd are preparing to leave the city. She might not have an opportunity to go if she waited until foreign troops arrive. July 29.

Last night soldiers and boxers attacked the Pei T'ang killing 100 of the inmates. An Italian was wounded by their own gun, this afternoon, in trying to knock down a Chinese barricade which had been put up against orders. They are blazing away at each other through loop-holes in their barricades and the Chinese.

July 30 .

Very noisy all night and still continues.

Saturday afternoon I chaperoned Miss Pierce and Mr. Duysberg over to look at the Japanese, French and German Legations. They are all very much damaged. We went down through the canal and came back on Legation street as it was quiet.

July 31 .

Last night two Chinese were beheaded as they were trying to enter the Chien-men (gateway). It is supposed they were messengers sent to us from Tientsin. Two others who managed to get through brought word that the troops were only 18 miles from here, that they had fought a battle on Sunday and had taken every village as they came along. We have heard so many rumors of relief being near that we shall not believe 
it until we see them. I feel as though I had seen quite enough of China and heathenism, and am ready to go back to the land of my birth and civilization.

Aug. 2nd.

Was very sick in bed eight days, but Mrs. Lowry has told me of all that has transpired during that time. I got so that I could not eat the horse meat any longer and it was that or starve so I concluded starvation was as good as horsemeat. I found a little corn-starch and with a little water and sugar (no eggs) the boy fixed it up and once or twice a day I had that. Chinese soldiers shot every one who went outside to look for eatables and no one was allowed to bring anything to us and here we are behind these walls like prisoners.

I heard great hurrahing at the bell tower just at sundown and Miss Peirce came to tell me of the good news. A messenger who had been sent from here some time ago and who was one of Dr. Lowry's converts at Hsiao-Shun-Hu-Tung, came from Tientsin with a number of messages. One letter from Mr. Ragsdale saying they never expected to see us again until they got Mr. Conger's telegram in July saying we were alive. There was a telegram from London saying they had seen Mr. Conger's message to the Department. It was the only thing they had been able to learn of anyone in Peking only what the Chinese Minister had informed them. They had been led to believe that we were being well cared for by Chinese officials, that we were all comfortable and happy. Here we have been since the early part of June with no communication whatever with the outside world. The messenger had his letters sewed between two old Chinese straw hats and no one suspected he had but one hat on. One of the letters said that on the 31st of July ten thousand troops would leave Tientsin for Peking, and that by the Middle of August 50 thousand would reach us if we could only keep up our courage a little longer.

Aug. 10.

We have not had one quiet night since Aug. 2nd. The Chinese seem to be getting more desperate every hour. The "old lady" has ordered two of the members of the Tsung-Li-Yamen beheaded, because they were inclined to be friendly to foreigners. We have had two and three attacks every night. 
Last night at dinner time they began at a furious rate and the British gave them a few greetings with "Betsy", the International, and they very shortly retired for refreshmentstea and a smoke, and to cool their heated brows. At 4 A.M. they seemed to be rested and began again more furious than before, but thank God none were killed but Chinese.

A messenger brought letters from the British and Japanese Generals saying the troops were half way here, that they had defeated the Chinese in two battles on the way up, and for us to keep up our courage yet a little longer, five or six days at the most and they would be here.

We had not finished our supper until they began popping away at us quite lively. 9:30 P.M. A heavy shower came down upon us and at the first clap of thunder the Chinese began to fire furiously and for half an hour or more it made us feel as though we were not out of the woods yet, if the troops were nearing.

I was told today that the chapel at Hsiao-Shun-Hu-Tung had not been burned as the boxers said a spook was on the roof and they were afraid to go near it. During the time the missionaries were all quartered there, Dr. Reed, a very tall slender man, had that as a place he was to watch at night and they were frightened away by his long legs.

Aug 11th.

Rather quiet last night, but considerable noise all forenoon. Aug 12.

A terrible racket all night and the greater part of the day. The heavy guns have fired more shots than ever before. (Our guns I mean.) Three attacks have been made since 12 oclock. We begin to feel that our troops are nearing and the Chinese think they must make the most of what little time they have, so they keep blazing away at us from every side. A German was wounded and a French Marine killed.

Prince Ching sent word today that the members of the Yamen were coming to see the Ministers tomorrow at eleven A.M. If I were in their places I would lock them up soon as they entered the gates and treat them exactly as they have been doing by us, then sieze the old lady and give her a dose of her own medicine. 
Aug 13.

The attack was very heavy last night. It seemed as if the walls around us would surely be blown down and we should all be killed before morning, but we are still alive.

Aug 14.

Last night was the worst of all. One German Marine was killed, our gunner wounded. And one Frenchman, one Russian, one Japanese Dr. was wounded also. A Russian was burried this forenoon who died in the hospital during the night.

Just after Mr. Bainbridge had come in from his watch and gotten to sleep I heard away off in the distance heavy cannonading and fireing which I knew was something I had never heard before and the more I listened the more I was convinced that relief was very near. Shortly I heard Mr. Conger's voice outside then all the ladies were out talking and laughing as I had not heard before in many long weeks. After an hour or so they all retired again and at 7 A.M. big guns were heard very near and we knew our troops were blowing down the wall to get into the city.

Aug 15-2:30 P.M. Shouts went up on all sides, "Soldiers are coming by the thousand." There was great rejoicing by every man, woman, and child. Some were shouting, others waving their handkerchiefs and others standing quietly with tears silently falling down their thin cheeks. 22 thousand came to our rescue on the first day. They had not been in over an hour before they began work on the Chinese. A company of Sieks (Indians) were sent out near our quarters to take a barricade and when they got over the wall there was not a Chinese to be found anywhere. So they settled themselves in the Imperial carriage grounds and had everything their own way. Troops were sent all around blowing down barricades with great success.

Aug 16.

The Americans fired on the Imperial city and captured it. We lost seven men in the fight,-Captain of the artilery and six privates were killed. The privates were burried in the American compound at 6 P.M. The Captain was burried at nine the next morning. All were put in one grave. 
Aug 17.

We were asked to give up our front room this morning as a hospital. There are only ten rooms in the Ministers house and thirteen which the 1st Secretary ${ }^{12}$ occupies, while we only had two. The one we are in has no window lights, and the outside blinds hang in all directions, bullet holes everywhere and just over my head is where a shell came through the roof and when it rains we usually know that it is damp inside as well as out.

Aug. 18th.

Baron Von Kettler's body was found yesterday at the Yamen and was burried in the German Legation this morning at 9 o'clock.

This evening Mr. B. and myself went down to see our Marines who had been removed from here to the Chien-men gate. I found two of them sick and they seemed quite pleased to see me. Before they left here some of them gave me some very nice little presents which I shall prize very highly, coming from the boys who fought so bravely for our lives for eight long weeks. I asked why they had given me such lovely things and one, with tears in his eyes said, "because you have treated us like white folks" and what you did for one was done for all. It has made my heart ache many times to see how worn and weary these poor boys look after such a siege. One of the sick ones held up his hand to show me how thin he was getting and remarked that the ring on his finger belonged to his mother, but she was dead, and he said I am afraid I shall loose it. Captain Myeres and Dr. Lippet are improving slowly.

Of the whole eight weeks of terrible anxiety and dread, three nights stand out with special prominence. They are spoken of by the besieged as "the three terrible nights." The first was a few night before we fled from our Legation. All night long went up terrible cries, howls and shouts of thousands upon thousands of Chinese crying for the blood of foreigners. The second was about the middle of the siege, when one of the most violent thunder storms I ever experienced

$12 \mathrm{Mr}$. Hubert Squiers. Referred to by Mr. Fleming as "the outstanding figure" in the American Legation; apparently Mrs. Bainbridge did not appreciate him as much. See, Fleming, op. cit., pp. 147-8. 
broke over the city. Every body had predicted the Chinese would cease firing, but the effect of the storms was just the opposite. It was a night of bellowing thunder, roaring artilery, incessant lightning and pouring rain. The third and last night of horrors was that of Aug. 13th, the day before the relief came. The Chinese were a howling frenzied mob and move Heaven and Earth to break in and kill us. Firing that had seemed furious was tame compared with the hail and shot and shell that poured in upon us that night, long to be remembered by us all.

We expected that any moment might be our last, as many breaches were made by shells and a determined assault at any one place would have opened the way for the hords outside, when at 2 A.M. on the 14th, faint sounds were heard away in the distance of, what seemed to us, like Heavenly music, nearer and nearer came the sounds of cannonading and artilery until every foreigner said in their hearts, "Thank God they are coming.

There was no mistake in that sound. All were up listening eagerly, rejoicing deep down in their hearts, "The troops are outside the city and we are saved." At eleven A.M. they reached the city wall and blew open places to come through. Some, however, scaled the wall, and the first man up was an Iowa boy. ${ }^{13}$ Hurrah for Iowa.

The siege of Peking was ended.

13 Calvin Pearl Titus of Vinton, Iowa. Born in 1879, he had served in the Salvation Army as a musician and as a missionary among the Western Indians. According to The Daily Iowa Capital (Aug. 25, 1900) he pawned his watch to pay for guardianship papers so that a guardian might give permission for him to enlist (his father's whereabouts were unknown and he was only 18 at the time). He was awarded the Congressional Medal of Honor. 
Copyright of Annals of Iowa is the property of State of Iowa, by \& through the State Historical Society of Iowa and its content may not be copied or emailed to multiple sites or posted to a listserv without the copyright holder's express written permission. However, users may print, download, or email articles for individual use. 